\title{
Pseudotail with closed neural tube defect and neurogenic bladder masquerading as posterior urethral valve: a case report
}

\author{
Ram Jeewan Singh* ${ }^{*}$, Md Mokarram Ali, Amit Kumar, Rashi Rashi, Amit Kumar Sinha and Bindey Kumar
}

\begin{abstract}
Background: Pseudotail with occult spinal dysraphism with neurological deficit is a rare phenomenon. Ignoring pseudotail as sign of occult spinal dysraphism may lead to catastrophe in diagnosis and further management.

Case presentation: We are reporting a case of a 30-month-old male child who presented with a tail-like structure at lower back and dribbling of urine since birth. On initial evaluation at some other hospital, he was misdiagnosed as posterior urethral valve and underwent fulguration of valve. However, dribbling of urine persisted after initial procedure. On evaluation at our center, he was found to have pseudotail with occult spinal dysraphism and neurogenic bladder.

Conclusion: Pseudotail with occult spinal dysraphism with neurological deficit is a rare phenomenon. Neurogenic bladder in such case can be misdiagnosed as posterior urethral valve. So, neurogenic bladder with pseudotail should be evaluated cautiously to avoid misdiagnosis and mismanagement.
\end{abstract}

Keywords: Human tail, Pseudotail, Posterior urethral valve, Occult spinal dysraphism, True tail

\section{Background}

A human tail is a rare congenital anomaly. The most common site of origin of human tail is the lumbosacrococcygeal region. Till date, around 60 cases have been reported in the literature [1]. Presence of human tail is a tell-tale sign of underlying spinal dysraphism and tethered cord [2] which may be associated with neurological deficit in the form of bowel/bladder incontinence and lower limb weakness. Neurogenic bladder is the most common urinary tract disorder in patients of spina bifida occulta [3]. We are going to present a case of pseudotail with lipomyelocele with neurogenic bladder masquerading as posterior urethral valve (PUV).

\section{Case presentation}

A 30-month-old male child was presented to our outpatient department with history of a tail-like structure at

* Correspondence: godlifelion@gmail.com

Department of Pediatric Surgery, AllMS Patna, Patna, India lower back since birth (Fig. 1). He also had history of urinary dribbling since birth and intermittent constipation after 6 months of age.

He had history of high-grade fever with dysuria at 1 year of age for which he was investigated in other government hospital and was diagnosed as posterior urethral valve (Fig. 2). After diagnosis of posterior urethral valve, transurethral fulguration was performed. Post fulguration, the urinary stream improved slightly but dribbling persisted. For urinary dribbling and tail-like structure at lower back, he consulted to our outpatient department. During visit at our institute, we advised and taught parents for clean intermittent catheterization (CIC). According to the parents, the tail was small at birth and gradually increased in size. On physical examination, the appendage was human tail-like, soft, well circumscribed, 4-cm long and $1-\mathrm{cm}$ thick, and was attached to the back of the sacrum. It was non-tender and covered with normal skin. There was no voluntary movement in the tail. Per abdominal examination,
Springer Open (c) The Author(s). 2021 Open Access This article is licensed under a Creative Commons Attribution 4.0 International License, which permits use, sharing, adaptation, distribution and reproduction in any medium or format, as long as you give appropriate credit to the original author(s) and the source, provide a link to the Creative Commons licence, and indicate if changes were made. The images or other third party material in this article are included in the article's Creative Commons licence, unless indicated otherwise in a credit line to the material. If material is not included in the article's Creative Commons licence and your intended use is not permitted by statutory regulation or exceeds the permitted use, you will need to obtain permission directly from the copyright holder. To view a copy of this licence, visit http://creativecommons.org/licenses/by/4.0/. 


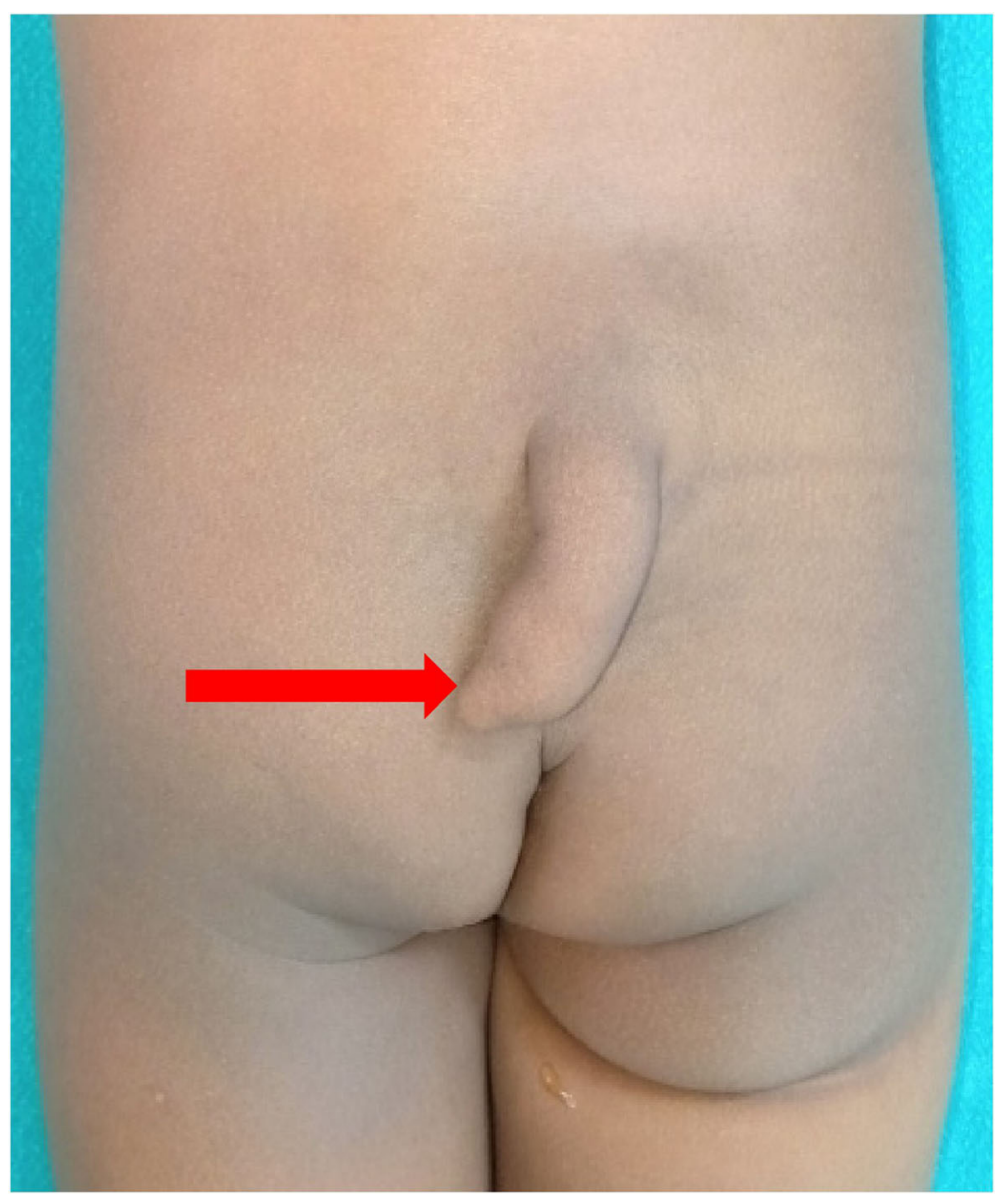

Fig. 1 The appendage (human tail—red arrow) was attached to the back of sacrum

bladder was palpable and expressible. Anal opening was patulous and normal in position. Bilateral lower limb weakness was present with limping gait. Other general and systemic examinations were normal. No obvious other congenital defect was noted. There was no family history of other developmental or congenital anomaly. The possibility of a human tail with underlying occult spinal dysraphism associated with neurogenic bladder and bowel was considered. Magnetic resonance imaging (MRI) of the spine was done which showed a sacral spinal dysraphism with lipomyelocele formation with extradural extension of fat and low-lying (L4) tethered spinal cord and pseudotail (Fig. 3).

After routine investigation, diagnostic cystoscopy for bladder pathology and excision and repair of lipomyelocele with laminectomy was planned. On diagnostic cystoscopy, bladder was trabeculated with mild dilatation of posterior urethra, but no obvious posterior urethral valve was seen. After cystoscopy, patient was positioned to prone for excision of pseudotail. With longitudinal elliptical skin incision around pseudotail with laminectomy of L4 vertebra, pseudotail along with extradural fat was removed. Spinal cord detethering was also done. Postoperative period was uneventful. Per urethral catheter was removed on postoperative day 5 , and patient was put on CIC. Patient was discharged on anticholinergic drug (oxybutynin) with advice of regular CIC. He was also advised high-fiber diet and laxative at night as a part of bowel management program. At 1 month followup, patient is doing well with no complaints of constipation and urinary incontinence. He is being planned for a follow-up with ultrasound of urinary tract to look for post void residue and isotope scan for the evaluation of renal scarring.

\section{Discussion}

Human tail is a midline protrusion in caudal region having combination of muscle, adipose tissue, and covered with skin [4]. During the 5th and 6th gestational week, the human embryo has a tail with 10-12 caudal vertebrae [1]. This tail usually regresses by reduction in the number of vertebrae and fusion, leaving behind the vestigial coccyx. It usually disappears by 8th week of gestation. On the basis of embryological origins, human tails 


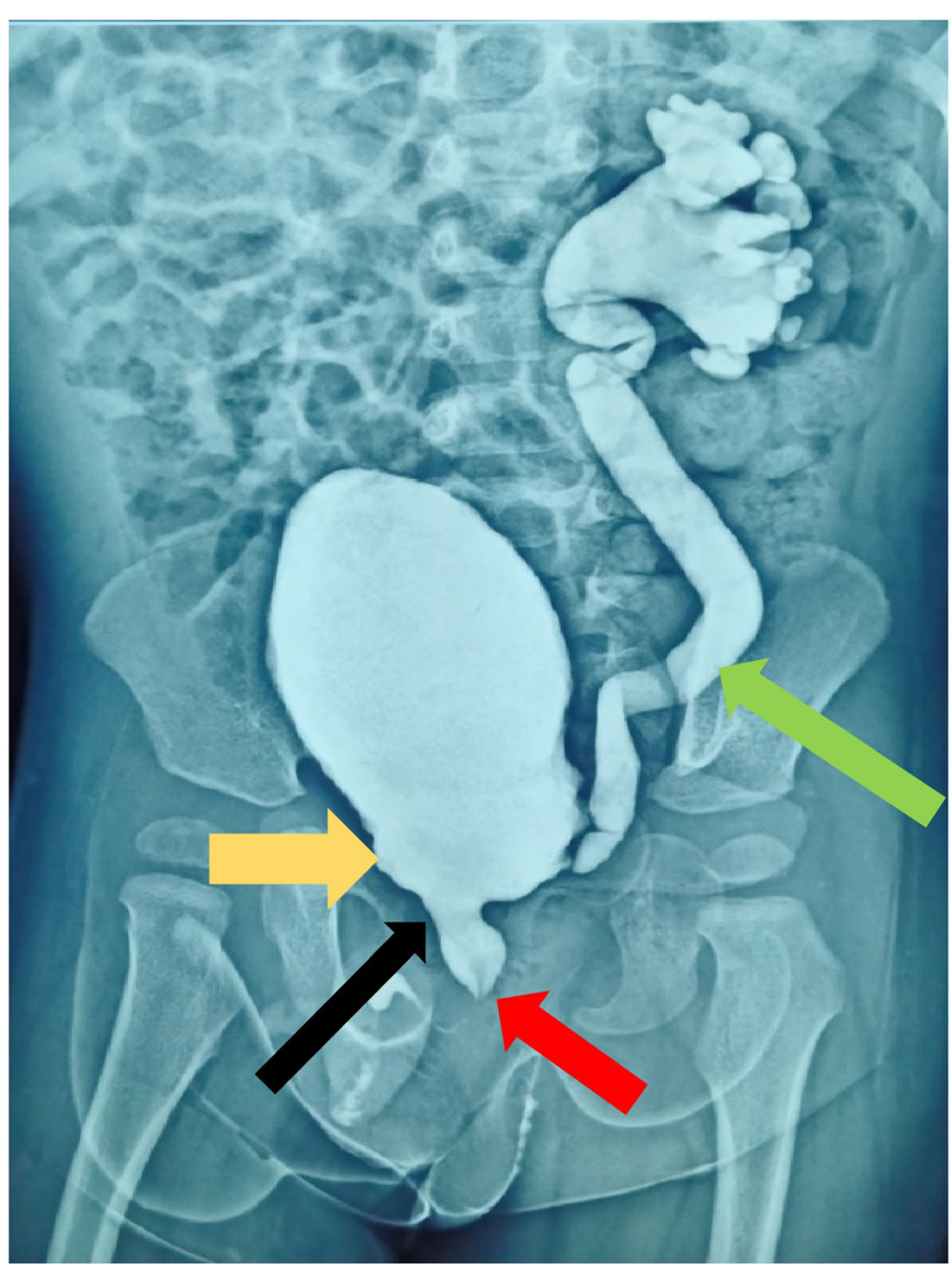

Fig. 2 Voiding cystourethrogram showing mildly dilated posterior urethra (red arrow), open bladder neck (black arrow), elongated bladder with trabeculation (yellow arrow), and left grade $V$ vesicoureteric reflux (green arrow)

are classified into two categories: true tails and pseudotail [5]. True tails are formed by embryological remnants which include muscle, adipose, and connective tissues. However, no vertebrae are seen in true tails. Pseudotails are lesions that have an underlying pathology such as spinal column and coccygeal malformations (lipoma or teratoma) [6]. Lu et al. [7] suggested that surgical excision is sufficient for true tail. He also described pseudotails as tail-like structure which is associated with spinal dysraphism. The human tail is considered to be a marker of underlying occult spinal dysraphism [8]. Pang et al. suggested that human tail is associated with high rates of spinal dysraphism (50\%) and tethered cord (81\%) [9].

Bladder dysfunction is common in spina bifida. Vesicoureteral reflux may occur in up to $40 \%$ of children with spina bifida by age 5 year. Sixty-one percent of young adults with spina bifida experience urinary incontinence [10]. The lower urinary tract symptoms depend on patient age during intervention and the level of spina bifida. Suprasacral lesions generally result in neurogenic detrusor overactivity with detrusor-sphincter dyssynergia [11]. In case of bladder sphincter dyssynergia, oblique voiding cystourethrogram demonstrate an unusual posterior urethral dilatation due to bladder contraction against the incompletely relaxed external sphincter giving false impression of posterior urethral valve [12]. The radiological signs of posterior urethral valve in voiding cystourethrography are dilated and elongated posterior urethra with normal anterior urethra with a ratio of more than 5:1 [13]. Other features are vesicoureteric reflux and trabeculated bladder with hypertrophied bladder neck. In index case, there was dilated posterior urethra due to neurogenic bladder which was wrongly interpreted and managed as posterior urethral valve.

Anticholinergic-like oxybutynin act as a bladder smooth muscle relaxant. They improve bladder dynamics by suppressing detrusor hypertonicity and hyperreflexia [14]. 


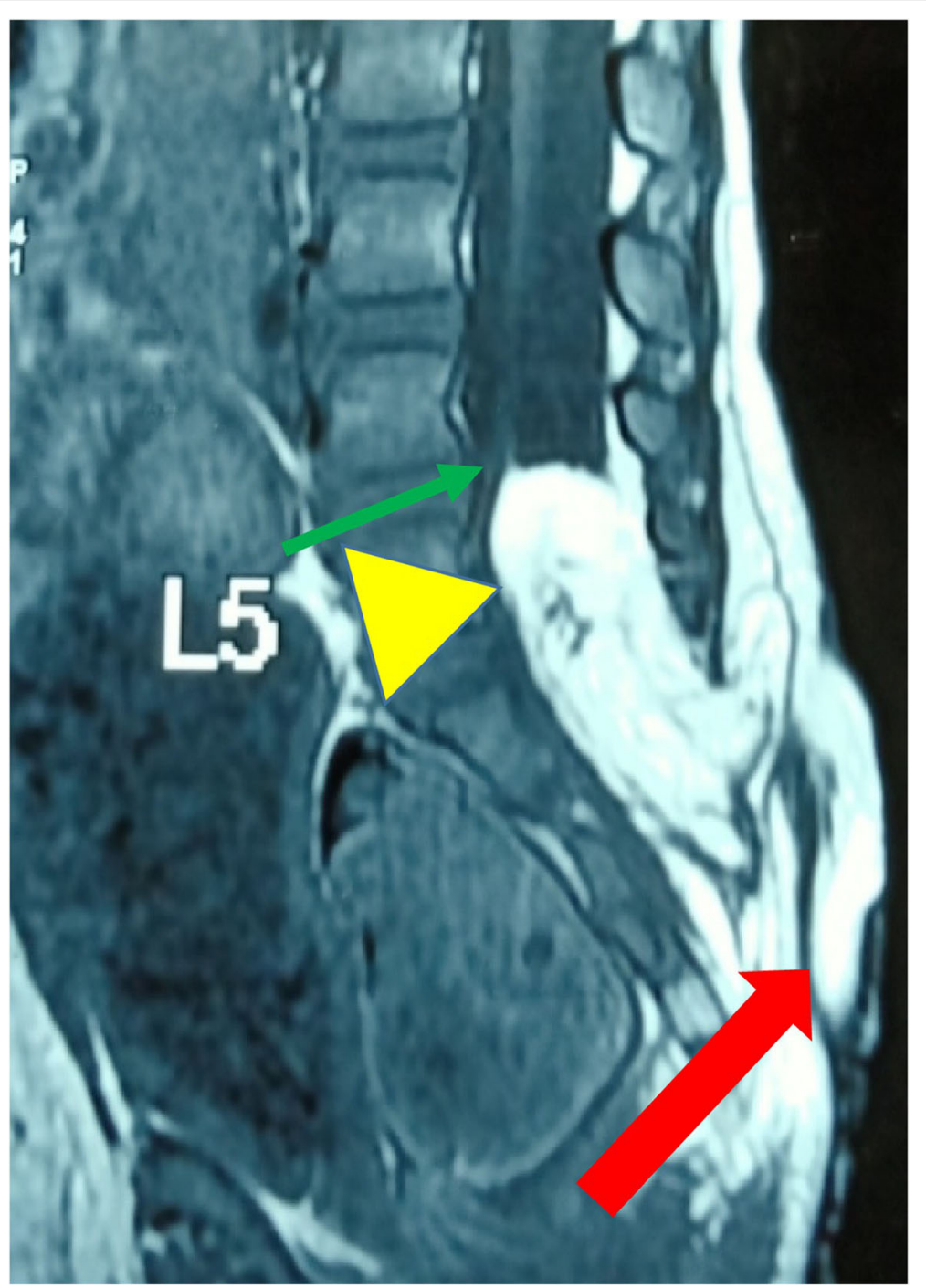

Fig. 3 Lipomyelocele with low-lying tethered cord at L4 (green arrow), extradural fat (yellow arrowhead), and pseudotail (red arrow)

Institution of bowel management program with high fiber diet, laxatives, and enema improves the symptoms of fecal and urinary incontinence in patients with neurogenic bladder due to spinal dysraphism [15].

\section{Conclusion}

Pseudotail with occult spinal dysraphism and neurological deficit is a rare phenomenon. In index case, due to its rarity and ignoring pseudotail as a marker of underlying occult spinal dysraphism, it was misdiagnosed and treated as posterior urethral valve. So, neurogenic bladder with pseudotail should be evaluated cautiously to avoid misdiagnosis. It is recommended that a careful physical examination, along with proper radiographic imaging of lumbosacral vertebrae help in diagnosing true or false tail and associated spinal dysraphism.

\section{Abbreviations}

MRI: Magnetic resonance imaging; CIC: Clean intermittent catheterization; PUV: Posterior urethral valve

Acknowledgements

Not applicable

\section{Authors' contributions}

RJS — manuscript writing and organizing pictures. MMA—editing and labeling pictures. AK and RR-literature searching. AKS-proof reading of manuscript. BK-conceptualization of manuscript. All authors have read and approved the manuscript.

Funding

None

Availability of data and materials Not applicable 


\section{Declarations}

Ethics approval and consent to participate

Not applicable

\section{Consent for publication}

Consent has been taken from parents for use of identifying images and other personal and clinical data of the patient. Written consent has been taken from parents for publication of this case report.

\section{Competing interests}

The authors declare that they have no competing interests.

Received: 14 March 2021 Accepted: 25 May 2021

Published online: 01 September 2021

\section{References}

1. Islam MN, Adhikari SB, Alam MM, DilshadMunmun UH. Experience with human tail and its outcome. Afr J Paediatr Surg. 2021;18(1):43-6. https://doi. org/10.4103/ajps.AJPS_48_20.

2. Donovan DJ, Pedersen RC. Human tail with noncontiguous intraspinal lipoma and spinal cord tethering: case report and embryologic discussion. Pediatr Neurosurg. 2005;41(1):35-40. https://doi.org/10.1159/000084863.

3. Johnston LB, Borzyskowski M. Bladder dysfunction and neurological disability at presentation in closed spina bifida. Arch Dis Child. 1988;79:33-8.

4. Shad J, Biswas R. An infant with caudal appendage. BMJ Case Rep. 2012; 2012:bcr1120115160.

5. Dao AH, Netsky MG. Human tails and pseudo-tail. Hum Pathol. 1984;15(5): 449-53. https://doi.org/10.1016/S0046-8177(84)80079-9.

6. Dubrow TJ, Wackym PA, Lesavoy MA. Detailing the human tail. Ann PlastSurg. 1988;20:340-4.

7. Lu FL, Wang PJ, Teng RJ, Yau Kl. The human tail. PediatrNeurol. 1998;19: 230-3.

8. Singh DK, Kumar B, Sinha VD, Bagaria HR. The human tail: rare lesion with occult spinal dysraphism - a case report. J PediatrSurg. 2008;43(9):e41-3. https://doi.org/10.1016/j.jpedsurg.2008.04.030.

9. Pang D, Zovickian J, Wong ST, Hou YJ, Moes GS. Limited dorsal myeloschisis: a not-so-rare form of primary neurulation defect. Childs NervSyst. 2013;29(9):1459-84. https://doi.org/10.1007/s00381-013-2189-2.

10. Verhoef M, Lurvink M, Barf HA, Post MWM, van Asbeck FWA, Gooskens RHJM, et al. High prevalence of incontinence among young adults with spina bifida: description, prediction and problem perception. Spinal Cord. 2005;43(6):331-40. https://doi.org/10.1038/sj.sc.3101705.

11. Abrams P, Cardozo L, Fall M, Griffiths D, Rosier P, Ulmsten U, et al. The standardization of terminology of lower urinary tract function: report from the standardization subcommittee of the International Continence Society. NeurourolUrodyn. 2002;21(2):167-78. https://doi.org/10.1002/nau.10052.

12. Fernbach SK, Feinstein KA, Schmidt MB. Pediatric voiding cystourethrography: a pictorial guide. Radiographics. 2000;20(1):155-68; discussion 168-71. 10682779. https://doi.org/10.1148/radiographics.20.1. g00ja12155.

13. Bani $\mathrm{HO}$, Prelog $\mathrm{K}$, Smith $\mathrm{GH}$. A method to assess posterior urethral valve ablation. J Urol. 2006;176(1):303-5. https://doi.org/10.1016/S0022-534 7(06)00562-3.

14. Verpoorten C, Buyse GM. The neurogenic bladder: medical treatment Pediatr Nephrol. 2008;23(5):717-25. https://doi.org/10.1007/s00467-0070691-z.

15. Radojicic Z, Milivojevic S, Lazovic JM, Becanovic S, Korićanac I, Milic N. The impact of bowel management on the quality of life in children with spina bifida with overactive bladder and detrusor sphincter dyssynergia. J Pediatr Urol. 2019 Oct;15(5):457-66. https://doi.org/10.1016/j.jpurol.2019.05.005.

\section{Publisher's Note}

Springer Nature remains neutral with regard to jurisdictional claims in published maps and institutional affiliations.

\section{Submit your manuscript to a SpringerOpen ${ }^{\circ}$ journal and benefit from:}

- Convenient online submission

- Rigorous peer review

- Open access: articles freely available online

High visibility within the field

- Retaining the copyright to your article

Submit your next manuscript at $\boldsymbol{\nabla}$ springeropen.com 